\title{
Cassava Value Chain mapping and Gender Role Analysis in Southeast Nigeria.
}

\author{
Osuji, M.N ${ }^{1}$, Mejeha, R.O ${ }^{2}$, Nwaru, $\mathrm{J}^{2}$, Nwankwo F.U ${ }^{3}$, Nwaiwu $\mathrm{U}^{1}$. \\ ${ }^{1}$ Federal University of Technology Owerri. \\ ${ }^{2}$ MichealOkpara University of Agriculture Umudike. \\ ${ }^{3}$ University of winipeg Canada
}

\begin{abstract}
The paper is on cassava value chain mapping and gender role analysis in southeast Nigeria. The objective of the study is to map the cassava value chain and to analyze the gender roles. A multi-stage sampling technique was used to select 288 respondents which include cassava producers, processors and marketers. Focus group discussion (FGD) and personal interview were used to collect primary data. Data were analyzed using the functional analysis tool, qualitative analytical tool and tables. The major findings were that majority of the producers do not source for inputs and implements from recognized source agent (input suppliers). It also shows that majority of the processors lack time and labour saving devices, the study shows that the market structure was poor and therefore all the actors involved in cassava value chain in the production of garri lack interdependency and collaboration leading to a weak and less sustainable chain. However, with awareness, mutual trust of the actors and information feed -back system along the chain, this will ensure that the chain is strengthened.
\end{abstract}

Keywords: Value chain, Mapping, Gender role, Southeast, Nigeria.

\section{Introduction}

Cassava is a major staple in most regions of the world. The regions of Asia, Africa and South America hold the product as an important component of daily household diet, livestock feed and as a raw material for industry. Africa is the world's largest cassava producing region accounting for nearly 55 percent of the world's cassava. It has enormous potential to improve food security and the livelihoods of people in Africa (James and Faleye, 2015). Nigeria is the highest cassava producer in the world, producing one - third more than Brazil and almost the double production capacity of Thailand and Indonesia (Nigeria Cassava Master Plan, 2006). Cassava has continued to play a remarkable role in the agricultural stage of Nigeria (Ahmed \&Idisi, 2014). Presently, Nigeria grows more cassava than any other country in the world.Gender roles refers to the distribution of responsibilities between men and women conditioned by sociological, political cultural, historical, economical and geographical factor,Gender roles are activities done by men and women which are not determined by biological factors, socio-economic, cultural environment or situation. (ICA-ILO 2001, Mollel and Mlenga 2000).Gender assumes the peculiarities, differences and complimentary of being male or female as it relates to society's way of defining the essence of manhood and womanhood.Gender affects every aspect of our lives as it affects the distribution of resources, wealth, work, decision making, political power as well as access to rights and privileges within the family and public life (Welch et al 2000).Value chain activities are mostly carried out by women, who are in charge of feeding their families; therefore a critical analysis on gender roles and its relationship with value chain are of utmost importance. The development of the chain and its combination with gender are based on what is already in existence (Laven et al, 2009 and Ezeibe et al, 2015).

Gender division of labour varies inNigeria, it varies in terms of farming systems, cultural settings, socio-political, ethnicity, income, status and decision making.In SoutheastNigeria, women are not left out as they work longer hours and are more likely to be involved in agriculture related activities to men (Odame et al, 2001, Ogato et al 2009) they carry the burden of reproduction work in addition to productive activities (JICA ,1999). In order to assist women to actively participate in value chain activities in Nigeria, policies, laws, attitudes and development programs which are favorable to women should be put in place.Maleness was considered as normal and femaleness a deviation from the normal ,(Ekong, 2003). While gender analysis gives insight into issues affecting women, it is focused mainly on the relationship of both men and women to the social and economic structure of the society (Unamma, 2002). As women are overburden, work longer hours, in the family and society and yet their status Quo remain the same. They still are found in the bottom of the pyramid with men still occupying the central role of decision making and management position this necessitated the writing of this paper.The broad objective of the study is to evaluateCassava value chain mapping and Gender Role Analysis in Southeast Nigeria. The specific objective is to identify the value chain actors and map their roles by gender. 


\section{Methodology}

This study was conducted in Southeast Nigeria, which is located between latitude $4^{0} 10^{1} \mathrm{~N}$ and $7^{0} 8^{1} \mathrm{~N}$ and longitude $5^{0} 30^{1} \mathrm{E}$ and $9^{0} 27^{1} \mathrm{E}$. The population of the zone is about $32,952,778$ people or $22.46 \%$ of the total population of Nigeria (NPC, 2006). The principal food crops are yam, cassava, cocoyam and maize while the cash crops are cocoa, oil palm, groundnuts, rubber and cotton (Okoye, 2010;Osuji et al. 2012;). The choice of southeast geopolitical zone for this study is informed by the fact that the zone is a leading producer of cassava and most families depend on the crop as a cheap source of carbohydrate.Cassava value chain was done by identifying and charting existing value chain as discovered during key informant and focus group discussion. Value chain mapping were done to identify men and women's position and roles in the chain and the type of activity that they are mostly involved in.

The objective of the study is to identify cassava value chain actors and their roles by gender and these were achieved using functional analytical technique. The value chain map is a functional analysis tool used to illustrate the functions of the various actors along the chain. A multi-stage sampling technique involving purposive, random and proportionate to size sampling procedures were adopted in the selection of respondents for the study. The sample is made up of 288 cassava producer, processors and marketers. This include 96 male and female producers. 96 male and female processors and 96 male and female marketers of garri. Focus group discussion (FGD) and interview schedule was employed to achieve data. The variables used included quantity of cassava produced, quantity of garri, market prices of input and output, volume of product, flow and quantity of product at each node. Data collected were analyzed using descriptive statistical tools such as percentages, tables, charts and frequency distribution and functional analytical tools such as value chain map.

\section{Mapping Cassava Value Chain Actors by Gender}

\section{Results And Discussion}

The Mapping of Cassava Value Chain Actors by Gender is presented in a figurewhile the actors roles are presented:

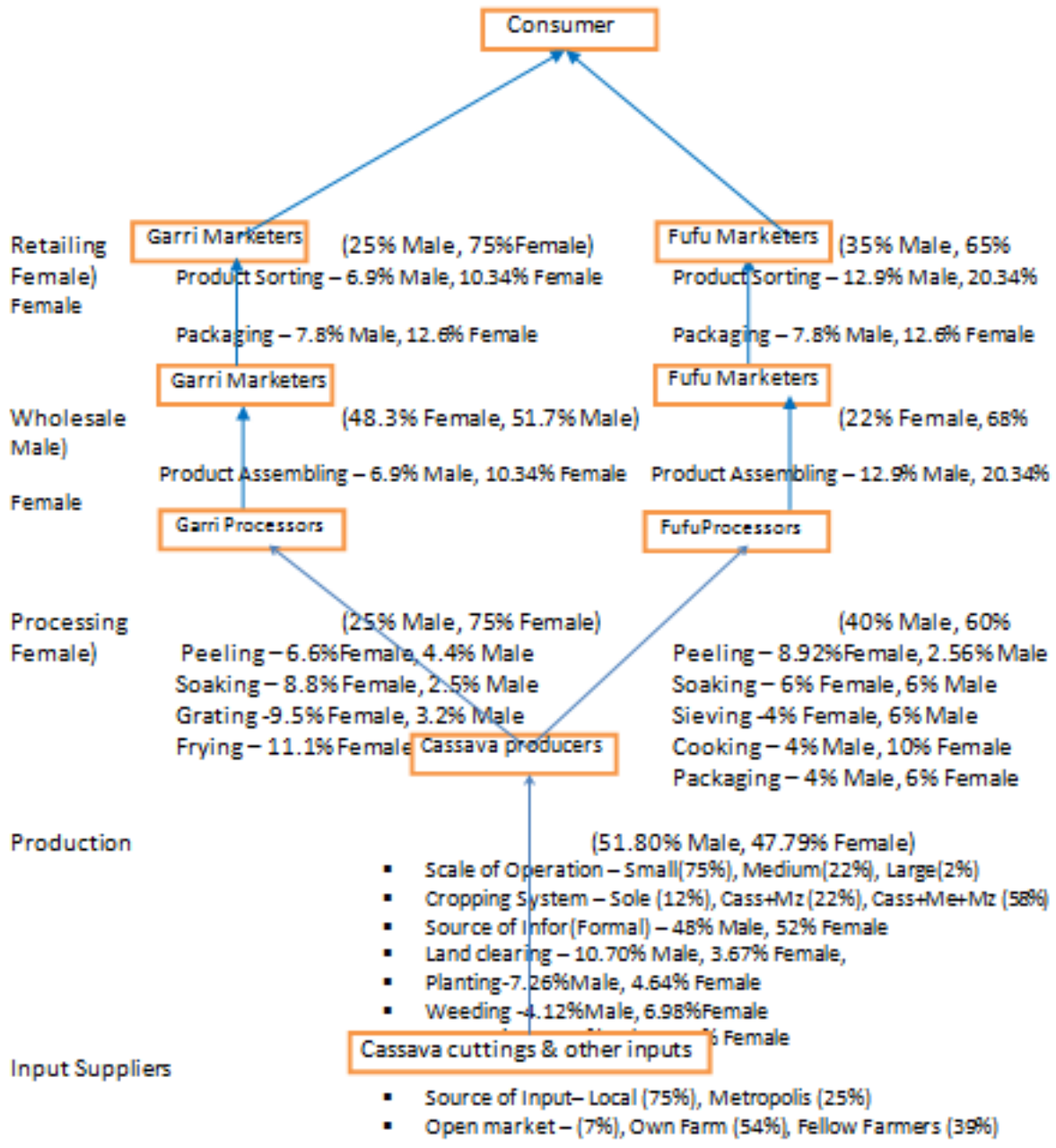

Figure 1.1: Cassava Value Chain Map in South East, Nigeria. 
Table 2.1: Functional Analysis of the Actors in Cassava Value Chain

\begin{tabular}{|c|c|c|c|c|}
\hline $\begin{array}{l}\text { Principal } \\
\text { Functions }\end{array}$ & Subdivisions & Actors & Principal Products & $\begin{array}{l}\text { Utility or } \\
\text { Value Added }\end{array}$ \\
\hline \multirow[t]{4}{*}{ Input Supply } & $\begin{array}{l}\text { Distribution and Market } \\
\text { training of farmers }\end{array}$ & $\begin{array}{l}\text { Agric Input } \quad \text { Supply } \\
\text { Agency (AISA), National } \\
\text { Root Crop. Umudike, farm } \\
\text { centers (govt owned ADP) }\end{array}$ & $\begin{array}{l}\text { Agrochemical and Fertilizer, } \\
\text { simple farm implements such } \\
\text { as knives shovel head pans and } \\
\text { cassava cuttings improved and } \\
\text { subsidized. }\end{array}$ & \multirow[t]{3}{*}{ Place Value } \\
\hline & $\begin{array}{l}\text { Distribution and } \\
\text { Marketing }\end{array}$ & $\begin{array}{l}\text { Independent Input Supplier } \\
\text { Public Shops fellow } \\
\text { farmers. }\end{array}$ & $\begin{array}{l}\text { Agrochemical and fertilizer } \\
\text { simple farm implements and } \\
\text { cassava cuttings. }\end{array}$ & \\
\hline & Lease & $\begin{array}{l}\text { Equipment dealers, state } \\
\text { and local government, } \\
\text { cooperatives }\end{array}$ & $\begin{array}{l}\text { Tractor, ploughs harrows, farm } \\
\text { tricycle. }\end{array}$ & \\
\hline & Land Preparation & $\begin{array}{l}\text { Hired labour, male } \\
\text { members of farmers } \\
\text { household, farmer. }\end{array}$ & Cassava cuttings Cassava stems & Form value \\
\hline \multirow[t]{3}{*}{$\begin{array}{l}\text { On-farm } \\
\text { production }\end{array}$} & Planting & $\begin{array}{l}\text { Farmer, hired labour, } \\
\text { family labour, exchange } \\
\text { labour. }\end{array}$ & Cassava cuttings & $\begin{array}{l}\text { Form and time } \\
\text { value }\end{array}$ \\
\hline & Maintenance/Mgt & $\begin{array}{l}\text { Farmer and hired labour } \\
\text { family labour. }\end{array}$ & Cassava cuttings & \\
\hline & Harvesting & $\begin{array}{l}\text { Farmers, hired labour, } \\
\text { family labour, exchange } \\
\text { labour. }\end{array}$ & Cassava roots & Form value \\
\hline $\begin{array}{l}\text { Postharvest } \\
\text { handling }\end{array}$ & Transporting & $\begin{array}{lr}\text { Head poterage } & \begin{array}{r}\text { processor } \\
\text { consumer } \\
\text { processors }\end{array} \\
\end{array}$ & $\begin{array}{l}\text { Cassava tubers, stems, rather } \\
\text { delivered to processors, } \\
\text { consumers or marketers. }\end{array}$ & $\begin{array}{ll}\text { Time, } & \text { price } \\
\text { and } & \text { place } \\
\text { value. } & \end{array}$ \\
\hline $\begin{array}{l}\text { Product } \\
\text { Transformati } \\
\text { on }\end{array}$ & Processing & $\begin{array}{l}\text { Garri processors both } \\
\text { industrial and small scale } \\
\text { processors women, fufu } \\
\text { processors. }\end{array}$ & Garri and fufu & Form value \\
\hline $\begin{array}{l}\text { Product } \\
\text { Trading }\end{array}$ & $\begin{array}{l}\text { Transportation } \\
\text { Marketing }\end{array}$ & $\begin{array}{l}\text { Wholesalers, retailers } \\
\text { major distributors, retail } \\
\text { outlets and supermarket } \\
\text { hawkers, shop sellers. }\end{array}$ & $\begin{array}{l}\text { Cassava flour, cassava flaks, } \\
\text { garri, fufuAbacha pellet }\end{array}$ & $\begin{array}{ll}\text { Time, } & \text { price, } \\
\text { and } & \text { place } \\
\text { value. } & \end{array}$ \\
\hline
\end{tabular}

Source: Field Survey Data, 2016.

\section{The Input Supplier}

\section{Functional Analysis Of Cassava Value Chain Actors And Roles}

The input suppliers are responsible for procuring inputs from manufacturers and research institutions and selling to farmers. Examples of such are fertilizers, herbicides, pesticides, improved cassava cuttings, farm tools such as matchets, hoes etc. They further render services such as instructions and advisory on the use of various inputs. The input supply in the communities were dominated by males, who easily travel long distances to purchase inputs or other implements from wholesalers or from research institutions. From the finding, less women are involved in input supply perhaps due to long distance, tediousness in movement attached to the job this agrees with the findings of John et al., (2013). Most farmers (75\%) sourced their inputs (Agrochemicals and tools) within their locality, while $(25 \%)$ sourced their inputs from urban metropolis such as Owerri and Nsukka.The input suppliers also provided cassava cuttings for some farmers (7\%) while most famers $(54 \%)$ sourced cassava cuttings directly from their farms and (39\%) from fellow farmers. This agrees with the findings of Adeoye et al., (2013), Mmasa and Msuya (2012) on plantain value chain mapping in South Western Nigeria and mapping of sweet potato value chain in Tanzania. They found that farmers usually acquire seeds for planting from fellow farmers and not from recognized sources agents. The input suppliers are at the bottom level in the chain and therefore do not play significant role in the study area. They also supply implements that relatively basic e.g (cutlass, files, hoes, shovel) and limited quantities of Agrochemicals. Most farmers (80\%) do not apply fertilizers. The communal exchange system of securing cassava cuttings is usual and known as peculiar of cassava value chain and has an inhibiting effect on the influence of input suppliers.

\section{Producers}

The producers (farmers) are responsible for the production of cassava roots. Their activities include establishment and management of the farm. Production of cassava is a labour intensive enterprise, it involves numerous procedures such as land clearing, land tillage, weeding planting of cassava stems, and harvesting. Most farmers use family labour or paid labour which they usually employ on daily basis. Men and women are in involved in different cassava production activities. Some activities are done by men while others are done by women. Almost all activities are done by both men and women, however some activities are referred to as men's or women's job, during this study the findings were that land clearing was mostly done by men and a few 
other activities. The rest of the activities that were done by women are planting, weeding and harvesting. Farmers in the study area are classified (based on farm hectarage of) while processors and marketers are classified (based on scale of operation) into subsistence into small scale commercial (75\%), medium scale commercial (22\%), and large scale commercials farmers (3\%). This is in line with Ayozieet. al. (2013), that any business or enterprise below the upper limit of N250,000 of fixed capital investment is a small scale industry, The result shows that majority of the farmers are small scale as seen that the mean hectarage. This is similar to the findings of TRIAS (2012) and Adeoye et al., (2013) these studies confirmed that small scale farmers were the main producers of cassava in Africa. Farmers in the study area inter- cropped cassava with other crops such as melon, maize, vegetable. Also from figure 1, major cropping systems identified were sole cassava (12\%) cassava and maize (22\%) cassava, melon and maize (58\%) cassava, melon, maize and vegetable (8\%). The farmers in the study area use rudimentary implements on their production activities. Most of the producers farmers (48\%) male and (52\%) female obtained information from their fellow farmers and informal sources while the rest $(52 \%)$ male and $(48 \%)$ female obtained information from formal sources.

\section{Processors}

Harvested cassava tubers were processed into different products such as garri, cassava flour, fufu, tapioca, cassava flakes, etc. The most popular cassava products were garri and fufu. Processors buy directly from producers/farmers. Cassava root produced in South East Nigeria undergo numerous processing before they reach different markets.The processing involves root preparation (peeling, slicing, washing) size reduction (grating) drying /dewatering, fermentation, sieving toasting or dry frying in the case of garriproduction . In the case of garri production, Men and women were found in this activity. It was found that majority of the women are responsible for root preparation and processes. The size reduction was mostly done by men as they operate the grating machine. Men and women were found to dry and dewater the cassava grated roots. Findings show that more women were involved in fermentation, sieving toasting or dry frying garri. Processed cassava products are widely sold and accepted in the study area but little has been done on international standards and exportability.

\section{Marketers}

Cassava products such as garri, fufu, abacha, tapioca and cassava flour are marketed in major markets in the study area and also the metropolises and urban market in the study area. Cassava products such as garri and fufu are traded in different markets which include local village markets, supermarkets in towns and cities, national markets and international markets. Each market usually represents different customers who demand for different quantities of garri. Majority of the cassava products garri are sold to whoever needs it at the market place and often at relatively better price, garri sales are done by both men and women. The wholesale marketing of garri is usually done by men while the retail components are dominated by women .This also agrees with the findings of John et.al., (2013).There is existence of wholesalers and retailers of cassava product in the study area, about $(50 \%)$ of the marketers interviewed were retailers of cassava products, while about $(50 \%)$ are wholesalers and major distributors. Wholesalers are major distributors of garri and fufu and they get their supply directly from processors. Most of the retailers take their product to urban markets to take advantage of higher profit margin.

\section{Consumers}

Cassava and its products are important staple in most households interviewed, garriare particularly eaten by all the families interviewed. Almost all families confirm that they eat cassava products either morning or lunch, some said they eat it twice daily. Consumers prefer high quality garri which fermented for about four days and also yellow colouredgarri due to the presence of oil which helps reduce the cyanide level.

\section{Conclusion}

Results show that most farmers reuse their cassava cuttings or source from fellow farmers. They do not utilize the availability of recognized source agents, ie the input suppliers who provide them with input e.g implements, fertilizer, herbicides and cassava cuttings with resistance to diseases. It was found that the input suppliers in the study area do not play significant roles in the chain development. The input suppliers bring only rudimentary implements and limited quantities of agrochemicals. They do not provide labour saving devices for the farmers and processors in the study area .

\section{Recommendation}

Input suppliers should be strengthen to be able to handle the task of agricultural value chain, they should be assisted through funding so that they can be able to provide improved varieties that are disease resistant and also provide improved machinery to enhance production.

The value chain actors in their various enterprises should be funded, trained and a frame work provided to better increase their interaction between and across anodes. 


\section{Reference}

[1]. Adeoye,I.B; Omobowole,A. O, Sulaiman A.Y \&Kemisola ,O.A (2013) Plantain value chain mapping in southern Nigeria. A Journal of economics and sustainable development .ISSN 2222-1700 (paper) VOL.4 NO 16.2013.

[2]. Ahmadu and Idisi (2014).Gender participation in cassava value chain in Nigeria. Merit research journal of agricultural science and Soil science (ISSN/2350/2274) Vol. 2 (11) pp147-153.

[3]. $\quad$ BNRCC (2011).Project Climate Change Scenero For Nigeria :Understanding Biophysical Impacts Climate Systems Analysis group ,A Report Published by The Building Nigeria Response to Climate Change ,University of Cape Town Rondebosch, South Africa.

[4]. $\quad$ Ekong, E. E (2003).An Introduction And Analysis Of Rural Nigeria, Dove Educational Publishers, Uyo Nigeria Pp316 -319.

[5]. Ezeibe, A.B, Edafiogho, D.O, Okonkwo ,N.A and Okide,C.C (2015) Gender differences and challenges in Cassava Production And Processing in AbiaState,Academic Journal vol 10(22)2259-2267.ISSN 1991-63x African Journal of Agricultural Research.

[6]. ICA-ILO 2001. Gender Issues in Cooperatives: An ICA-ILO Perspective.

[7]. James, D and Faleye (2015).cassava mechanization prospects and future in Nigeria.International research journal of agricultural science and soil science.ISSN:22510044,Vol.5(3)pp.91021 2015.

[8]. Japan International Cooperation Agency (JICA) 1999.Country WID Profile (Ethiopia).Tokyo: JICAPlanning Department

[9]. Jeckoniah .J, Mdoe.N,Nowibo .C (2013). Mapping of gender role and relations along onion value chain in North Tanzania , International journal of Asian social science 3 (2): 523-541.

[10]. Laven, A, A. Van Eerdewijk, A. Senders, C. Van W.And R Snelder, 2009. Gender In Value Chains: Emerging Lessons And Question. A. Working Paper (Kit, Cidin, Hivos, Agri-ProfocusAnd ICCO). 1 -13.

[11]. Macionis, J. J. (1996).Society: The Construction And Representation Of Agriculture Based Masculinities" Australian And New Zealand Journal Of Agriculture 68(4). Pp 605 - 620

[12]. Mgbada J.U (2000). Production Of Stable Crops By Rural Women In Enugu And Ebonyi States. In T. Olowu (Ed) Extension Poverty Alleviation In Nigeria Proceedings Of The $6^{\text {th }}$ Annual National Conference Of The Agricultural Society Of Nigeria, Pp10 12.

[13]. Mmasa J.J and MsujaE.E (2012): Mapping of the sweet Potato value chain Linkages between Actors, Processes and Activities in the Value chain: A Case of "Michembe" and "Matobolwa" Products. www.ccsenet.org/sar Sustainable Agriculture Research Vol. 1, No. 1; February 2012.

[14]. Mollel NM, Mtenga NA 2000.Gender Roles in the Household and Farming Systems of TechenzemaMorogoro-Tanzania. South African Journal of Agricultural Extension,29: 73-88.

[15]. National Population Commission (NPC,2006) Census Publication

[16]. Nigeria Cassava Master Plan (2006). A Strategic Action Plan For The Development of The Nigeria Cassava Industry. UNIDO pp.42-50.

[17]. Nwachukwu, .S. (2005) .The Need For Value Adding Activities: A Micro and Small Business Perspective for Africa, Paper Presented at Makerere University Business School Second Annual Entrepreneurship Conference ,Kamapala Uganda.

[18]. Odame, H.H., Hefkin, N., Wesseler, G., Boto, I. Gender and agriculture In: the information society intervention Service for National Agricultural research, 2002, Briefing paper No. 55. The Hague, The Netherlands: ISNAR

[19]. Ogato, G.S., Boon, E.K., Subramani, J. Improving access to productive resources and agricultural services through gender empowerment:A case study of three rural communities in Ambo district,Ethiopia. Journal of Human Ecology, 2009. 27, No.2, 85 100 .

[20]. Okoye B.C (2010). Analysis Of Market Participation Among SmallHolder Cassava Farmers In Response To Transportation Costs In South East Nigeria. Unpublished Ph. D-Thesis Agricultural Economics Department, MOUA, Umudike

[21]. Osuji, M.N., Ohajianya, D.O.,Lemchi,J.I., Eze, C.C.,Henri-Ukoha.A and Onwuagba, I.J (2012). Determinants of revenue among small holder irrigation vegetable farmers in Imo state of Nigeria. International Journal of Agriculture and Rural Development,15(3),1212-1215.

[22]. TRIAS (2012): Subsector Analysis Report. A Report Prepared for TRIAS Sub Sector Studied: Banana [Matooke]n(Musa spp., AAA-EA genome).

[23]. Unamma (2002).Gender impact in agricultural technology adoption and commercialization. Paper presented at FAO/11TA workshop on gender impact and commercialization of small holder agriculture held at $11 \mathrm{~T}$, Ibadan $14^{\text {th }}-16^{\text {th }}$ may $\mathrm{p} 150$.

[24]. Welch, C. J, Alemu B, Msaki T, Sengendo M, KiguthaH,Wolff A 2000. Improving Household Food Security:Institutions, Gender, and Integrated Approaches.U.S.A: BASIS Management Entity.

[25]. https://en.wikipediadia. Org /wiki/capacity-building. 